\title{
Advances in mechanochemical processes for biomass valorization
}

\author{
Camilla Maria Cova ${ }^{1}$ and Rafael Luque ${ }^{1,2^{*}}$ (D)
}

\begin{abstract}
Compared to standard time and solvent consuming procedures, mechanically-assisted processes offer numerous environmentally-friendly advantages for nano-catalytically active materials design. Mechanochemistry displays high reproducibility, simplicity, cleanliness and versatility, avoiding, in most cases, the use of any solvent. Moreover, mechanically-assisted procedures are normally faster and cheaper as compared to conventional processes. Due to these outstanding characteristics, mechanochemistry has evolved as an exceptional technique for the synthesis of novel and advanced catalysts designed for a large range of applications. The literature reports numerous works showing that mechanosynthetic procedures offer more promising paths than traditional solvent-based techniques. This review aims to disclose the latest advances in the mechanochemical assisted synthesis of catalytically active materials, focusing on nanocatalysts designed for biomass conversion and on bio-based catalysts.
\end{abstract}

Keywords: Mechanochemistry, Catalysis, Bio-based catalysts, Biomass conversion

\section{Introduction}

\section{Mechanochemistry timeline}

As formalized by IUPAC, a mechanical-assisted reaction is "a reaction caused by the mechanical energy" [1]. In fact, mechanical actions, such as compression, stress, or friction, usually provides the energy to activate a process. According to Takacs, the most ancient document concerning a mechanical-assisted process is described in a book in 315 B.C.. The document, titled "On Stones", was written by Theophrastus, one of Aristotle's students. The philosopher-scientist described the reduction of cinnabar $(\mathrm{HgS})$ to mercury $\left(\mathrm{Hg}^{0}\right)$ using a copper vessel and a copper pestle filled with some vinegar (containing acetic acid) [2, 3]. After that first experiment reported by Theophrastus, no mechanicalbased protocols were reported for the following 2000 years. Only in 1820 mechanochemistry appeared again, when Faraday carried out mechanical-assisted trials, reducing $\mathrm{AgCl}$ to elemental $\mathrm{Ag}$ using zinc, copper, tin or iron in a pestle. Faraday noticed that mechanicalassisted reaction could give different products compared to the ones obtained by normal thermal heating.

\footnotetext{
* Correspondence: q62alsor@uco.es

1Departamento de Química Orgánica, Universidad de Córdoba, Edificio Marie-Curie (C-3), Ctra Nnal IV-A, Km 396, Cordoba, Spain

${ }^{2}$ Peoples Friendship University of Russia (RUDN University), 6 Miklukho Maklaya str, 117198 Moscow, Russia
}

Specifically, he proved that the mechanical-assisted processes favoured the decomposition of $\mathrm{Ag}$ and $\mathrm{Hg}$ halides to their elements by chemical reaction, rather than by melting or sublimation [4]. A few years later, Wilhelm Ostwald (1853-1932) definided "mechanochemistry" as one of four chemistry disciplines (together with photo-, electro- and thermo-chemistry). In 1894, Gerard Heinicke formalized mechanochemistry as "the discipline relative to physical-chemical modifications of the solid produced by the action of mechanical factors" [5]. Figure 1 gives a summary of the milestones of mechanochemistry evolution.

\section{Mechanochemistry theory}

The principal feature of mechanical-assisted process is the achievement of chemical changes by the only action of grinding (or milling), without needing to dissolve reagents (therefore without using any solvent). Grinding is a broad term that describes the effect of mechanical forces on a compound that allow a solid breaking into small parts. By grinding, the improved potential energy together with friction and shear contributions, generate surface and shape defects in the reactants. These defects can considerably change the reactivity of chemicals, giving the final product, as described in Fig. 2. 


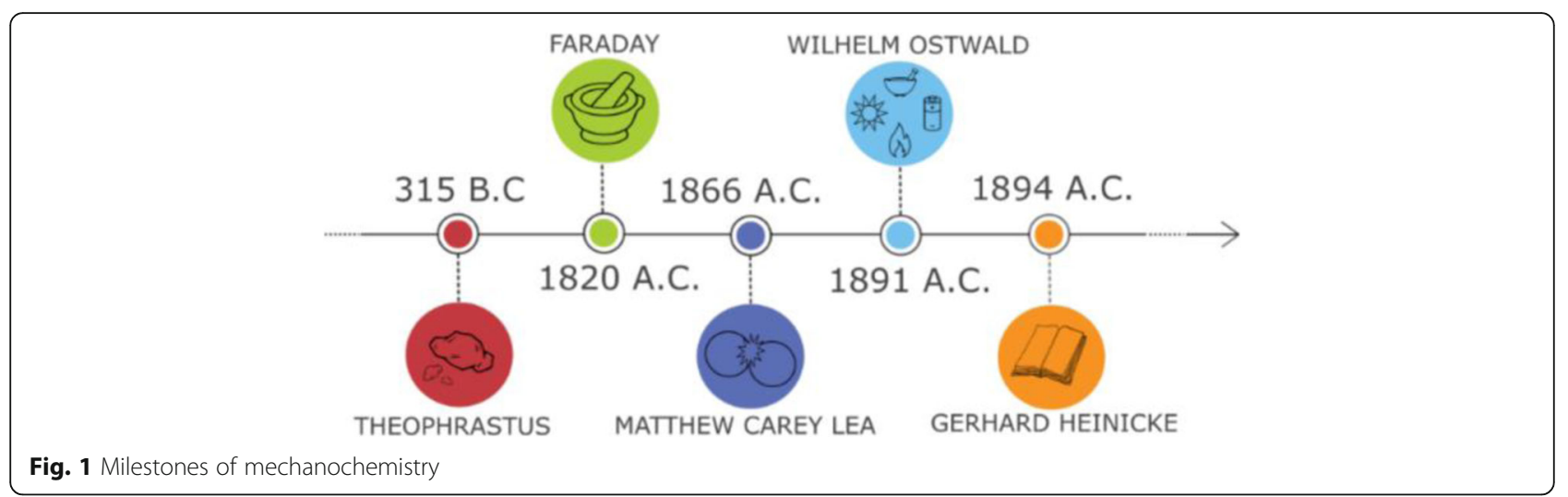

\section{Mechanochemistry equipment}

Mechanical-assisted processes could be carried out using different equipment based on manual methods (mortar and pestle) or non-manual methods, such as mixer mills [6]. Mortars and pestles were largely studied in the past especially because they are the cheapest tools for conducting mechanical-assisted protocols. Unfortunately, many environmental factors can influence the aforementioned instruments. In addition, these manual methods do not allow properly controlling the protocol parameters such as frequency or grinding force. Consequently, nowadays the use of this type of equipment can be considered obsolete. Recently, more advanced non-manual instrumentations have been developed in order to achieve highly

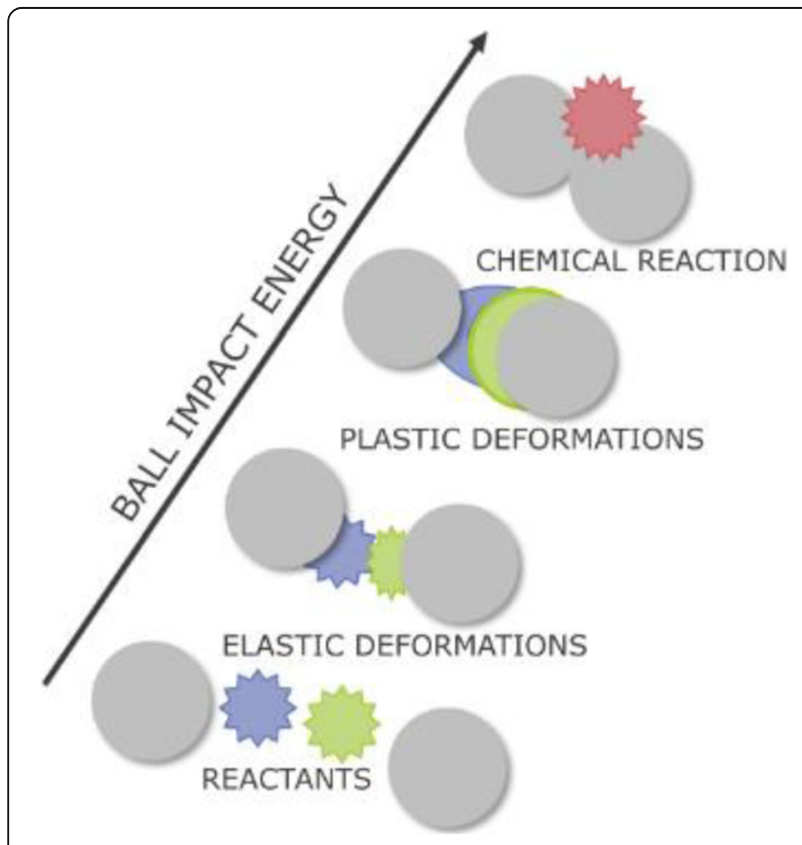

Fig. 2 Mechanochemical reactions: from reactants to products reproducibility of the mechanochemical synthesis. These tools include, among the others, mixer and planetary mills, and offer the possibility to accomplish solvent-free processes through well-defined reaction parameters, such as milling force and grinding speed.

\section{Mechanochemical-related literature}

The study of mechanical-assisted processes has increased considerably, especially in the last 5 years [7], as showed in Fig. 3.

Historically, most of the publication has focused on the mechanical-assisted synthesis of different intrinsically insoluble inorganic material. In the last years, an increasing number of publications were related to the application of mechanical-assisted protocols in organic chemistry. Finally, the newest works re-designed the concept of mechanochemistry, exploiting mechanochemicalassisted techniques for the preparation of novel nanocatalytic materials [8].

\section{Scope of the review}

Notably, most studied methods for the synthesis of nanocatalysts include sol-gel methods, impregnation, precipitation, hydrothermal procedures and microwaveassisted techniques [9-11]. These protocols have successfully led to the synthesis of advanced catalysts, but they also show numerous drawbacks. In details, these methods are normally time and solvent-consuming, expensive and need aggressive reaction conditions. In this context, mechanical-assisted processes have been proposed as alternative paths for the industrially applicable synthesis of nanocatalysts. In fact, thanks to easiness, versatility and solvent-free conditions, mechanochemistry can compete with standard synthetic methods, avoiding multi-step routes, traditional heating and any addition of toxic reagents. A wide range of nanocatalysts have been synthetized using mechanical-assisted methods. Most studied applications of mechanicalsynthesized catalysts include energy and environmental 


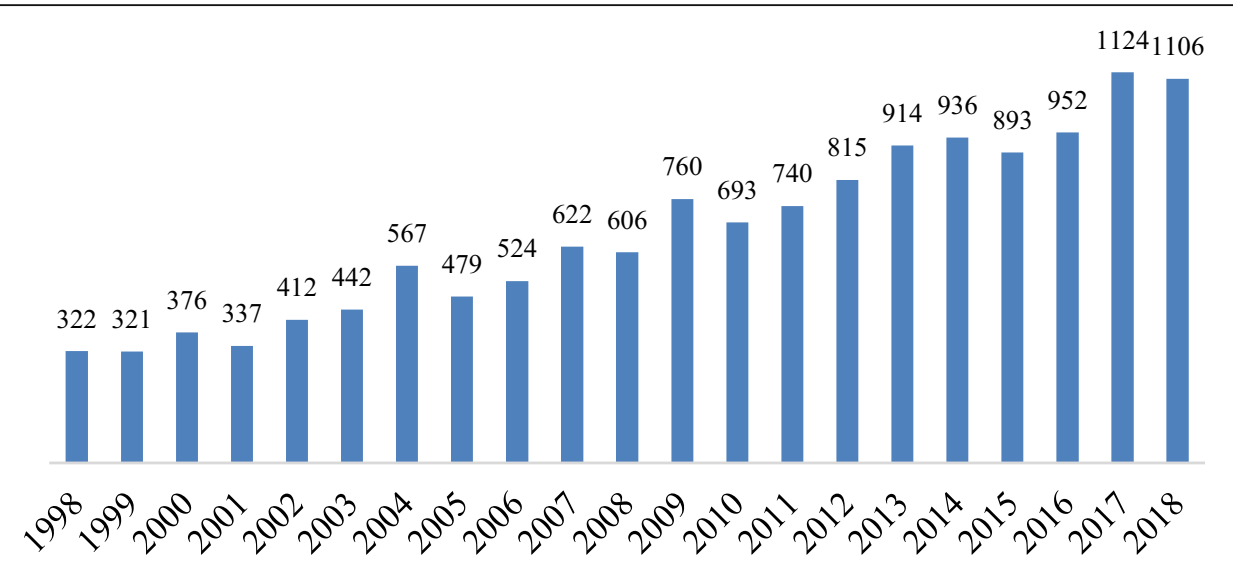

Fig. 3 Total publications (yearly) in the mechanochemistry field. Data taken from SciFinder Web

uses or applications in organic synthesis [12-17]. Among all these applications, an interesting sub-class is represented by mechanochemical-synthesized nanocatalyst used for biomass valorization. This review aims to illustrate key examples of these types of novel materials. In particular, a first section is dedicated to the mechanochemically assisted synthesis of nanocatalysts used for biomass conversion reactions. The subsequent part discloses mechanochemical-assisted protocols for the preparation of bio-based catalytically active materials. Figure 4 schematizes the scope of the review.

\section{Mechanochemically-assisted protocols for nanocatalysts preparation}

Mechanochemically prepared nanocatalysts for biomass conversion

The design of nanocatalysts for biomass conversion has become a very hot topic since the society have started the ambitious transition to a bio-based circular economy [18].

In fact, especially in the last decades, biomass has emerged as an alternative and renewable feedstock which can be converted into valuable materials and chemicals using different protocols that include greener and environmentally friendly paths respect to traditional routes $[19$,
20]. A key factor for the valorization of biomass through the different processes, is the utilization of an efficient catalyst. The most important characteristic that a catalyst used for biomass valorization must have is the stability under the conditions in which the biomass is normally treated. These include highly stability to moderate-high pressure/ temperature and to the presence of water. These characteristics can be effectively found in nanocatalysts prepared with a suitable mechanochemical synthesis.

For examples, highly active nanocatalysts prepared by mechanosynthesis have been employed to produce vanillin. Vanillin is a broadly used aromatic compound in the food industry and in cosmetic formulations and consequently its synthesis is of considerable economic interest. However, the traditional synthetic procedures of this compound requires petro-derivatives and non-environmental friendly protocols. Therefore, more green and alternative methodologies have been studied. Specifically, isoeugenol and vanillyl alcohol can be employed as bio-based starting chemical. In fact, both isoeugenol and vanillyl alcohol are producted from lignin, one of the most abundant biowaste.

In a recent publication, an effective process to obtain vanillin from raw materials derived from lignin (isoeugenol) has been studied [21]. Fast kinetics and high selectivity were achieved using transition metal-

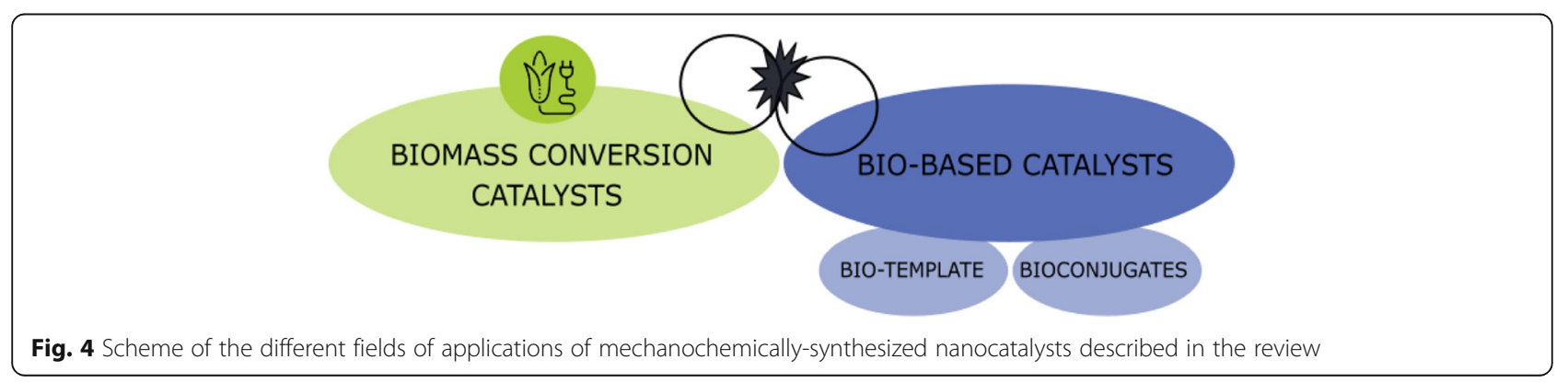




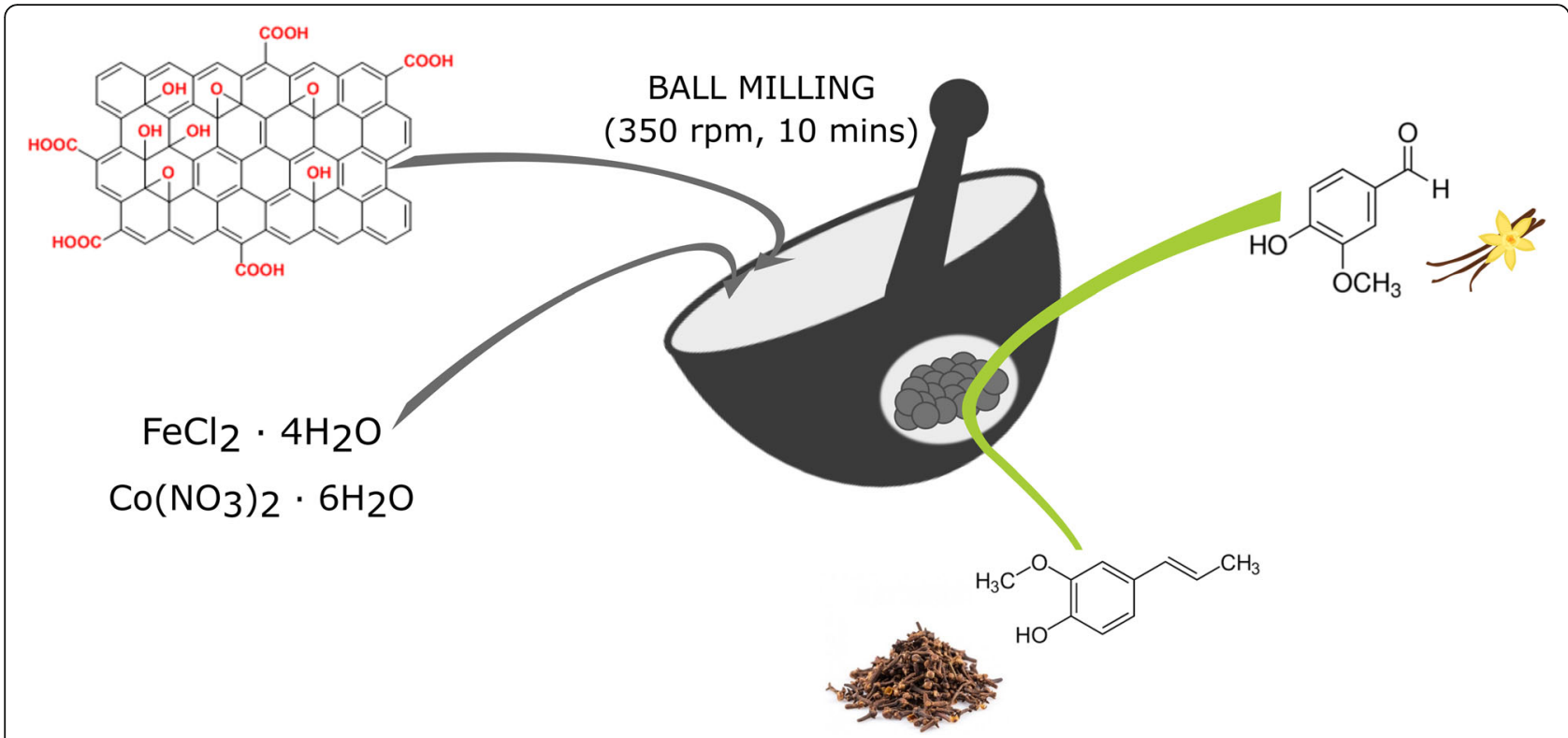

Fig. 5 Overview of the preparation and application of the $1 \%$ wt. Fe (or Co) /graphene oxide catalysts

based catalysts. The metals were supported on reduced graphene using simple, clean and fast mechanical-assisted protocols. In details, the supporting material of reduced graphene oxide was mixed with the iron salt $\left(\mathrm{FeCl}_{2} \cdot 4 \mathrm{H}_{2} \mathrm{O}\right)$ in order to support $1 \%$ weight of metal and subsequently subjected to grinding under mild conditions $(350 \mathrm{rpm}, 10 \mathrm{~min})$ in a ball mill. The preparation of the $1 \%$ wt. cobalt catalyst was carried out via the same mechanical-assisted protocol, using $\mathrm{Co}\left(\mathrm{NO}_{3}\right)_{2} \cdot 6 \mathrm{H}_{2} \mathrm{O}$ as metal precursor. The iron or cobalt-based nanocatalyst were tested in the reaction of isoeugenol oxidation, achieving good conversion and remarkable selectivity using hydrogen peroxide as oxidant. The mechanical-assisted procedure was proved to be a valid alternative synthesis for Fe and Co catalysts, showing outstanding activity for biomass conversion, as schematized in Fig. 5 .

A mechanochemical-assisted protocol was also designed to obtain a magnetic material $\mathrm{Fe}_{2} \mathrm{O}_{3}$-based using mesoporous silica (Al-SBA-15) as supporting material [22]. The mechanical-assisted preparation of $\mathrm{Fe}_{2} \mathrm{O}_{3}$ particles on Al-SBA-15 was achieved by milling
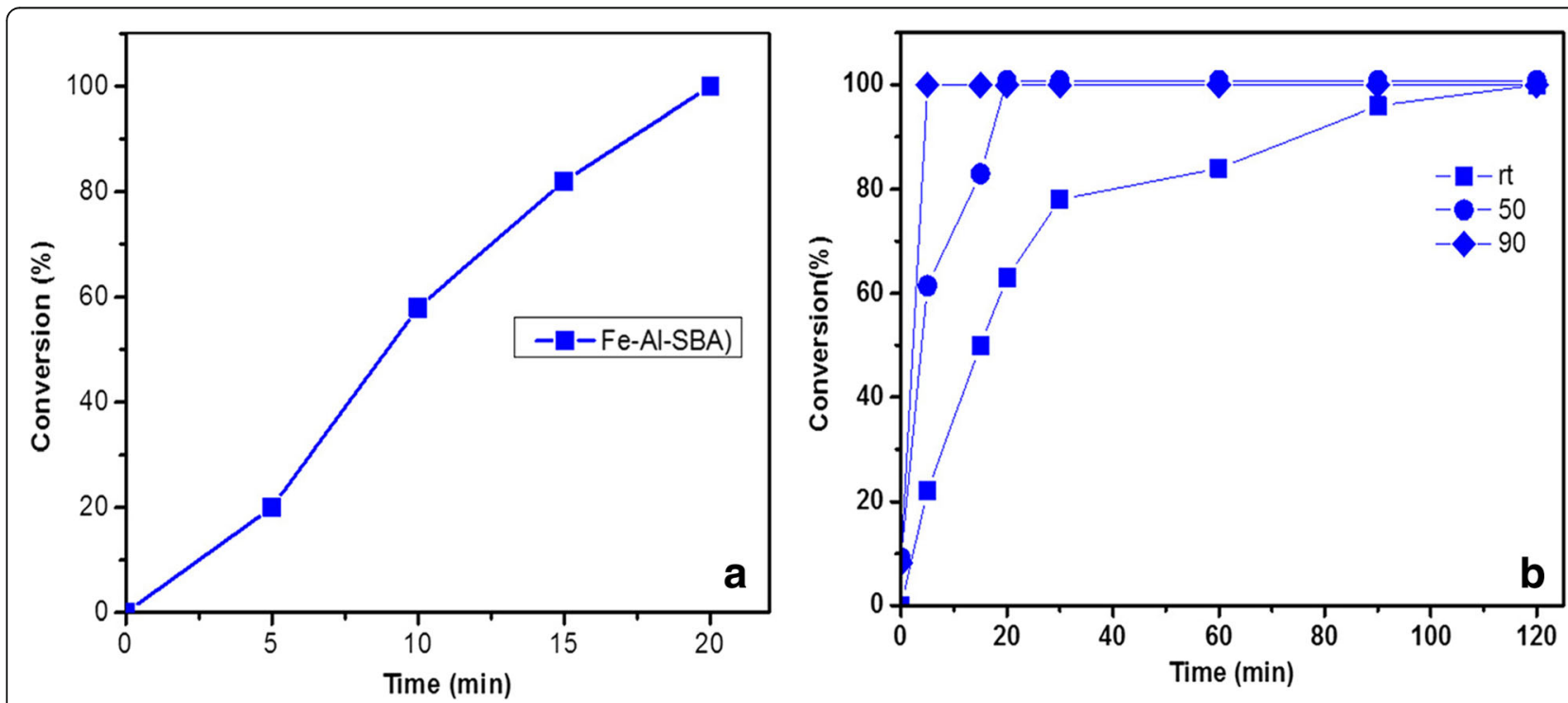

Fig. 6 a Kinetic analysis of the oxidation of vanillyl alcohol for $20 \mathrm{~min}$ at $50^{\circ} \mathrm{C}$ and $\mathbf{b}$ catalytic behavior at different temperature for $120 \mathrm{~min}$. Reprinted with permission from Ref. [22] Copyright (2019) Elsevier B.V 


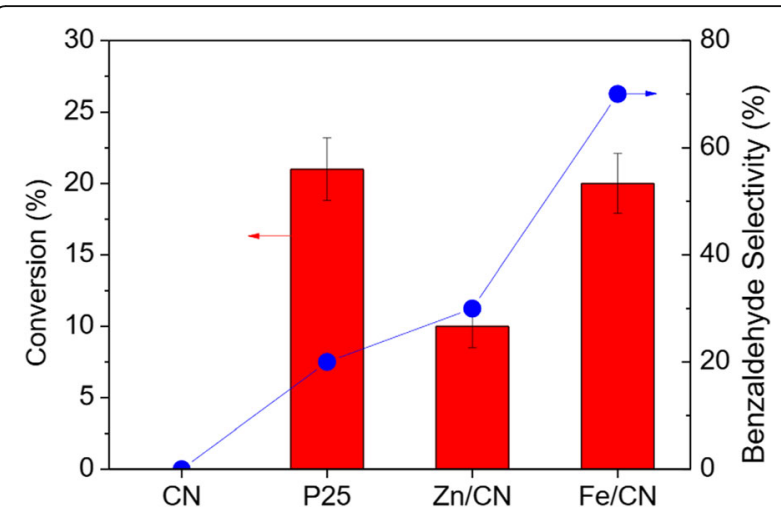

Fig. 7 Activity and selectivity in the photo-oxidation of benzyl alcohol for the graphitic carbons nitride enriched with zinc or iron. Reprinted with permission from Ref. [23] Copyright (2019) Elsevier B.V

together propionic acid, $\mathrm{Fe}\left(\mathrm{NO}_{3}\right)_{3} \cdot 9 \mathrm{H}_{2} \mathrm{O}$ and Al-SBA15 at $350 \mathrm{rpm}$ for $10 \mathrm{~min}$. The following step of the protocol was a calcination one at $300^{\circ} \mathrm{C}$ for half an hour. The synthesized materials were tested in the synthesis of vanillin through the oxidation of vanillyl alcohol, showing great selectivity and conversion, as displayed in Fig. 6. Interesting, the material was demonstrated to possess a great stability in the aforementioned oxidation, since the activity did not decrease also after 10 cycles of reuse.

Another captivating biomass-derived chemical is benzyl alcohol, which can be oxidized to benzyl aldehyde. This last compound is a highly demanded product as it is extensively employed as ingredient in the food or in the pharmaceutical industry or as a fragrance for cosmetic formulations, or even as an intermediate in many chemicals synthesis.

Recently, graphitic carbon nitride $\left(\mathrm{g}-\mathrm{C}_{3} \mathrm{~N}_{4}\right)$ doped with zinc oxide or iron oxide were prepared using a one-step mechanical-assisted protocols [23]. The oxide incorporation on graphitic carbon nitride was obtained by a simple mechanical-assisted step in a planetary ball mill for 10 min at $350 \mathrm{rpm}$. Zinc oxide and $\mathrm{Fe}_{2} \mathrm{NO}_{3}$ were used as precursors. Lastly, the material was calcined at $300^{\circ} \mathrm{C}$ for $3 \mathrm{~h}$. The prepared materials were used as catalysts for the selective benzyl alcohol photo-oxidation to benzaldehyde. Both prepared composite materials showed an improvement of selectivity (70\%) and conversion (20\%) with respect to pure $\mathrm{g}-\mathrm{C}_{3} \mathrm{~N}_{4}$ used as reference, as displayed in Fig. 7.

The selective oxidation of benzyl alcohol could be also achieved using cobalt oxide nanoparticles supported on mesoporous silica (SBA-15). The catalyst was prepared through a mechanochemical-assisted protocol. Briefly, the appropriated amount of cobalt precursor was milled with $2 \mathrm{~g}$ of SBA- 15 metallosillicate at $350 \mathrm{rpm}$ for $10 \mathrm{~min}$. This first step was followed by a calcination at $400{ }^{\circ} \mathrm{C}$ for $4 \mathrm{~h}$. The soprepared material was tested in the selective oxidation of benzyl alcohol, allowing conversions up to $40 \%$. Moreover, the efficiency of the cobalt-based catalysts was proved in the alkylation of toluene with benzyl chloride, achieving complete conversion to alkylated derivatives in a very short time [24].

Similarly, novel copper-containing aluminosilicate materials were synthetized using a mechanical-assisted protocols. Two types of aluminosilicate catalyst with and without zinc were tested. A typical preparation includes the milling of $1 \mathrm{~g}$ of Al-SBA-15 or AlZn-SBA-15 and the correct quantity of a copper precursor $\left(\mathrm{CuCl}_{2} \cdot 2 \mathrm{H}_{2} \mathrm{O}\right)$ in order to reach $2 \mathrm{wt} \%$. The reactants were milled together in a ball mill (Retsch 100) at $350 \mathrm{rpm}$ for $10 \mathrm{~min}$ [25]. Lastly, the materials were calcined in air at $400^{\circ} \mathrm{C}$ for 4 $\mathrm{h}$, as showed in Fig. 8.

The catalysts were tested in the microwave-assisted valorization of glucose to the value added product 5methylfurfuryl alcohol (5-MFA). Firstly, glucose was dehydrated with formic acid and subsequently hydrogenated to 5-MFA. This unprecedented mechanicalassisted protocol could pave the way for upcoming studies for the preparation of a wide range of products with high added value from sugars.

Table 1 , briefly summarizes the works described above for biomass conversion using mechanochemically synthesized materials.

\section{$1^{\circ}$ step BALL MILLING \\ (350 rpm, 10 mins)}

Al-SBA-15 / AlZn-SBA-15

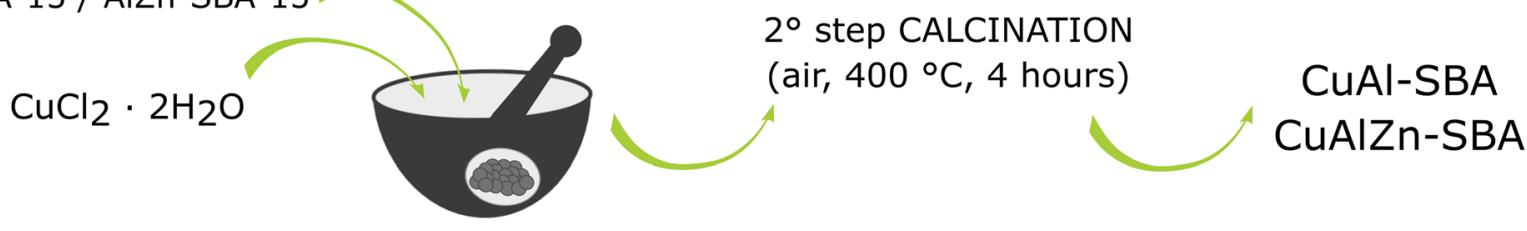

Fig. 8 Pictorial representation of the synthetic procedure of CuAI-SBA and CuAIZn-SBA 
Table 1 Summary of mechanochemically prepared catalysts for biomass conversion

\begin{tabular}{|c|c|c|c|c|}
\hline Catalyst & Preparation method & Equipment & Application & Ref. \\
\hline $\begin{array}{l}1 \% \text { wt Fe (Co) /graphene } \\
\text { oxide }\end{array}$ & $\begin{array}{l}\text { Ball milling graphene and } \mathrm{FeCl}_{2} \cdot 4 \mathrm{H}_{2} \mathrm{O}\left(\mathrm{or} \mathrm{Co}\left(\mathrm{NO}_{3}\right)_{2} \text {. }\right. \\
\left.6 \mathrm{H}_{2} \mathrm{O}\right) \text { in a planetary ball mill for } 10 \mathrm{~min} \text { at } 350 \mathrm{rpm} \text {. }\end{array}$ & $\begin{array}{l}\text { Retsch-PM-100 } \\
\text { planetary ball mill }\end{array}$ & $\begin{array}{l}\text { Production of vanillin from isoeugenol, } \\
\text { a lignin-derived feedstock. }\end{array}$ & {$[21]$} \\
\hline $\begin{array}{l}\mathrm{Fe}_{2} \mathrm{O}_{3} \text { supported on } \\
\mathrm{Al}-\mathrm{SBA}-15\end{array}$ & $\begin{array}{l}\text { Al-SBA-15, Fe }\left(\mathrm{NO}_{3}\right)_{3} \cdot 9 \mathrm{H}_{2} \mathrm{O} \text { and propionic acid were } \\
\text { used as chemicals and were milled in a planetary ball } \\
\text { mill at } 350 \mathrm{rpm} \text { for } 10 \mathrm{~min} \text {. Finally, the material was } \\
\text { calcined at } 300^{\circ} \mathrm{C} \text { for } 30 \mathrm{~min} \text {. }\end{array}$ & $\begin{array}{l}\text { Retsch-PM-100 } \\
\text { planetary ball mill }\end{array}$ & $\begin{array}{l}\text { Production of vanillin from vanillyl } \\
\text { alcohol, a lignin-derived materials. }\end{array}$ & [22] \\
\hline $\begin{array}{l}\text { Graphitic carbon nitride } \\
\text { enriched with } \mathrm{ZnO} \text { or } \\
\mathrm{Fe}_{2} \mathrm{O}_{3}\end{array}$ & $\begin{array}{l}\mathrm{ZnO} \text { (or } \mathrm{Fe}_{2} \mathrm{NO}_{3} \text { ) were supported on graphitic carbon } \\
\text { nitride using a mechanical-assisted step in a planetary } \\
\text { ball mill for } 10 \text { min at } 350 \mathrm{rpm} \text {. Lastly, the materials } \\
\text { were calcined at } 300^{\circ} \mathrm{C} \text { for } 3 \mathrm{~h}\end{array}$ & $\begin{array}{l}\text { Retsch-PM-100 } \\
\text { planetary ball mill }\end{array}$ & $\begin{array}{l}\text { Selective photo-oxidation of benzyl } \\
\text { alcohol to benzaldehyde. }\end{array}$ & [23] \\
\hline $\begin{array}{l}\text { Co oxide nanoparticles } \\
\text { supported on mesoporous } \\
\text { material }\end{array}$ & $\begin{array}{l}\mathrm{CoCl}_{2} \cdot 6 \mathrm{H}_{2} \mathrm{O} \text { together with } 2 \mathrm{~g} \text { of support were } \\
\text { milled at } 350 \mathrm{rpm} \text { for } 10 \mathrm{~min} \text { in a planetary ball mill; } \\
\text { then the materials obtained were calcined at } \\
400^{\circ} \mathrm{C} \text { for } 4 \mathrm{~h} \text {. }\end{array}$ & $\begin{array}{l}\text { Retsch-PM-100 } \\
\text { planetary ball mill }\end{array}$ & $\begin{array}{l}\text { Oxidation of benzyl alcohol and } \\
\text { alkylation of toluene. }\end{array}$ & [24] \\
\hline $\begin{array}{l}\text { CuAIZn-SBA and } \\
\text { CuAI-SBA }\end{array}$ & $\begin{array}{l}\text { Ball milling solid support and } \mathrm{CuCl}_{2} \cdot 2 \mathrm{H}_{2} \mathrm{O} \text { in a } \\
\text { planetary ball mill for } 10 \mathrm{~min} \text { at } 350 \mathrm{rpm} \text {, followed } \\
\text { by calcination at } 400^{\circ} \mathrm{C} \text { for } 4 \mathrm{~h} \text {. }\end{array}$ & $\begin{array}{l}\text { Retsch-PM-100 } \\
\text { planetary ball mill }\end{array}$ & $\begin{array}{l}\text { Microwave-assisted conversion of } \\
\text { glucose to products with high } \\
\text { added value. }\end{array}$ & {$[25]$} \\
\hline
\end{tabular}

\section{Mechanochemically prepared bio-based materials for energy conversion/storage and photodegradation}

A recent innovative approach in mechanochemistry is the utilization of biological/natural compounds as sacrificial templates or as bio-conjugates in the synthesis of nanocatalysts. In the last years, the interest in the use of diverse biomass sources as sacrificial template has been growing. In fact, the use of natural template sources is extremely attractive for the preparation of nanocatalysts in ecological friendly ways, avoiding the utilization of toxic or expensive classical templates [26]. These bio-templates materials include starch [27-30], cellulose [31], chitosan [32-35], lignin $[36,37]$ and alginate $[38,39]$. Compared to classical templates, these materials are also often employed in milder reaction conditions [40].

For example, the synthesis of porous zinc oxide nanomaterials was carried on employing zinc nitrate with various polysaccharides including a biomass-derived agar extracted from Gracilia gracilis, as sacrificial template [41]. An easy mechanical-assisted step was efficiently carried out. The milling step was followed by calcination at $600{ }^{\circ} \mathrm{C}$ in order to remove the template. The prepared materials were tested for phenol degradation displaying an encouraging photocatalytic activity. Due to its simplicity, large applicability and reproducibility, the proposed mechanical-assisted process has a remarkable potential and could be employed to obtain alternative nanocatalysts from different metal oxides.

Schneidermann et al. have prepared nitrogen-doped carbon using a mixture of lignin with a mechanicalassisted one-pot process [36]. The synthesis was carried out using a sustainable, available, cheap and largely diffuse precursor. The nitrogen-doped carbons were synthetized milling together, in a zirconia vessel for $30 \mathrm{~min}$, the product of the carbonization of a mixture of lignin (wasted

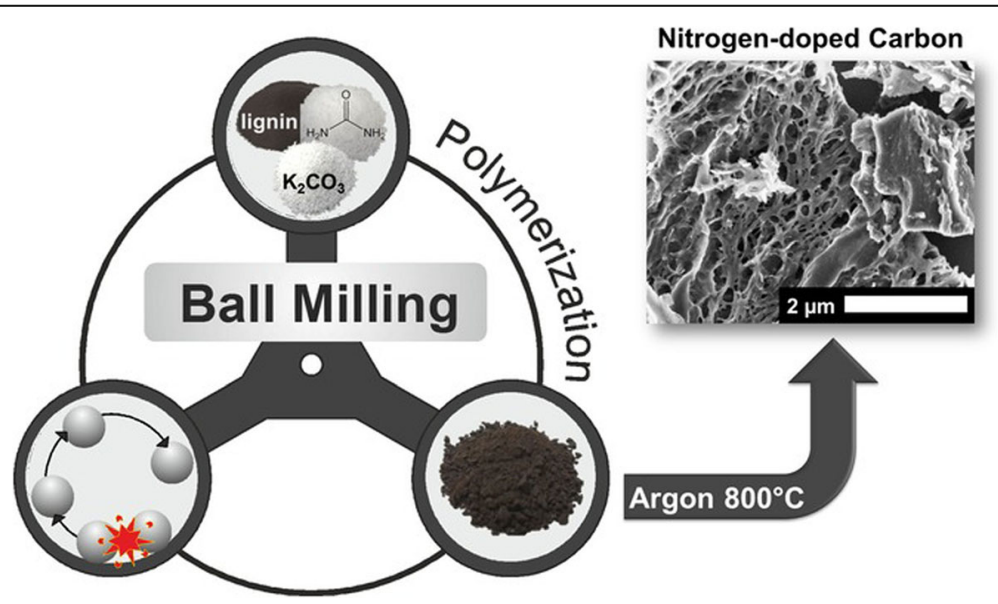

Fig. 9 Pictorial representation of the synthetic procedure of N-doped porous carbon. Reprinted with permission from Ref. [36] Copyright (2017) Wiley-VCH 


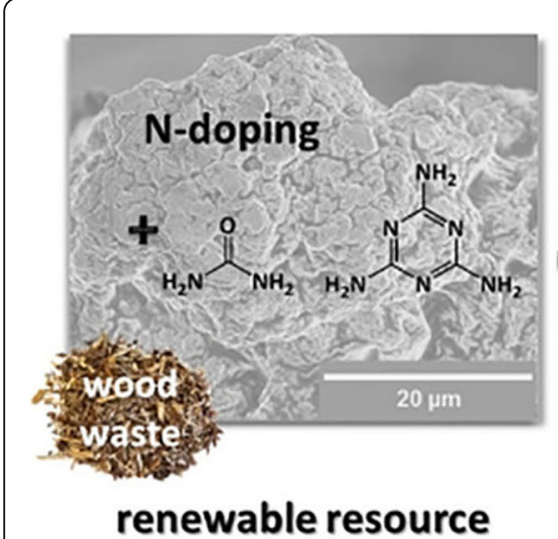

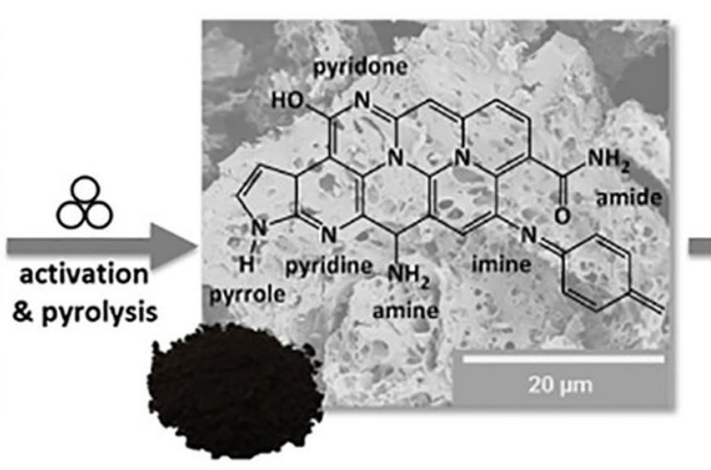

$\mathrm{N}$-doped carbon

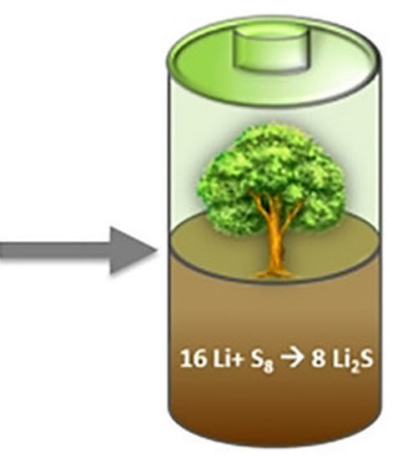

energy storage

Fig. 10 Mechanical step and carbonization of a mixture of sawdust, urea and/or melamine and $\mathrm{K}_{2} \mathrm{CO}_{3}$ to prepare $\mathrm{N}$-doped carbons as electrode for lithium-sulfur batteries. Reprinted with permission from Ref. Reprinted with permission from Ref. [37] Copyright (2019) Wiley-VCH

from pulp industry) as carbon precursors, urea as nitrogen source and potassium carbonate as activation agent. The obtained materials were sequentially carbonized at $800^{\circ} \mathrm{C}$. Remarkably, carbons showed excellent performance as supercapacitor. The mechanical-assisted protocol was demonstrated to be an environmentally friendly alternative route to obtain nitrogen-doped materials from sustainable precursor. The protocol is schematized in Fig. 9.

More recently, the aforementioned researchers have carried out a mechanical-assisted synthesis of $\mathrm{N}$-doped carbons using renewable biomass waste. In particular they used sawdust, an agricultural by-product, as sacrificial template [37]. Sawdust was used as carbon precursor, melamine and/or urea as a nitrogen precursor, and $\mathrm{K}_{2} \mathrm{CO}_{3}$ as an activation agent. In a typical mechanochemical procedures, the three precursors were milled for $30 \mathrm{~min}$. The mechanical-assisted step was followed by a carbonization of the obtained polymer at $800^{\circ} \mathrm{C}$. The nitrogen-doped carbon materials showed a good performance as cathode for lithium-sulfur batteries. The adopted approach is schematically presented in Fig. 10.

Usually, the preparations of nitrogen-doped carbons involve multiple process steps, which are time-, energy- and solvent-consuming and they often employ expensive chemicals. Furthermore, many traditional routes produce large amounts of wastes, especially solvents, which are potentially harmful to the environment or even toxic to humans $[42,43]$. The two syntheses of nitrogen-doped carbon materials described above are based on economic and non-toxic feedstock and follow environmentally friendly synthetic paths. Synthetic methods and applications of mechanically obtained nanocatalysts using biomass-template materials are summarized in Table 2.

Besides the aforementioned application of biomass as carbon precursors, our group has extended the mechanochemistry field to synthetize bioconjugates-based materials. In the literature, different paths have been explored to functionalize biological molecules on magnetic nanoparticle surfaces. However, almost all reported protocols need the use of solvents. In order to obtain bio-modified magnetically recoverable nanocatalyst in an easier and less toxic way, mechanical-assisted synthesis was employed reducing reaction time and avoiding solvent consumption [44]. For example, a bio-modified nanomaterial was prepared using horse hemoglobin $(\mathrm{Hb})$ and

Table 2 Summary of mechanochemically prepared biomass-template catalysts

\begin{tabular}{|c|c|c|c|c|c|}
\hline Catalyst & $\begin{array}{l}\text { Biomass } \\
\text { template }\end{array}$ & Preparation method & Equipment & Application & Ref. \\
\hline $\begin{array}{l}\text { Porous } \mathrm{ZnO} \\
\text { nanomaterials }\end{array}$ & Polysaccharides & $\begin{array}{l}\text { Ball milling of zinc nitrate and polysaccharide } \\
\text { at } 350 \mathrm{rpm} \text { for } 10 \mathrm{~min} \text {, followed by calcination } \\
\text { in air at } 400^{\circ} \mathrm{C} \text { for } 4 \mathrm{~h} \text {. }\end{array}$ & Retsch-PM-100 planetary ball mill & $\begin{array}{l}\text { Photocatalytic phenol } \\
\text { degradation }\end{array}$ & {$[41]$} \\
\hline $\begin{array}{l}\text { N-doped } \\
\text { carbon }\end{array}$ & Lignin & $\begin{array}{l}\text { Milling the carbonization of lignin, urea and } \\
\text { potassium carbonate for } 30 \text { min; then } \\
\text { carbonization at } 800^{\circ} \mathrm{C} \text {. }\end{array}$ & $\begin{array}{l}\text { Fritsch Pulverisette } 7 \text { premium line } \\
\text { planetary ball mill }\end{array}$ & $\begin{array}{l}\text { Cathode for lithium-sulfur } \\
\text { batteries }\end{array}$ & [36] \\
\hline $\begin{array}{l}\text { N-doped } \\
\text { carbon }\end{array}$ & Sawdust & $\begin{array}{l}\text { Sawdust melamine and/or urea and } \mathrm{K}_{2} \mathrm{CO}_{3} \\
\text { were milled for } 30 \mathrm{~min} \text { in a zirconia vessel. } \\
\text { Then the obtained polymers were } \\
\text { carbonized at } 800{ }^{\circ} \mathrm{C} \text {. }\end{array}$ & $\begin{array}{l}\text { Fritsch Pulverisette } 7 \text { premium line } \\
\text { planetary ball mill }\end{array}$ & Supercapacitors & {$[37]$} \\
\hline
\end{tabular}




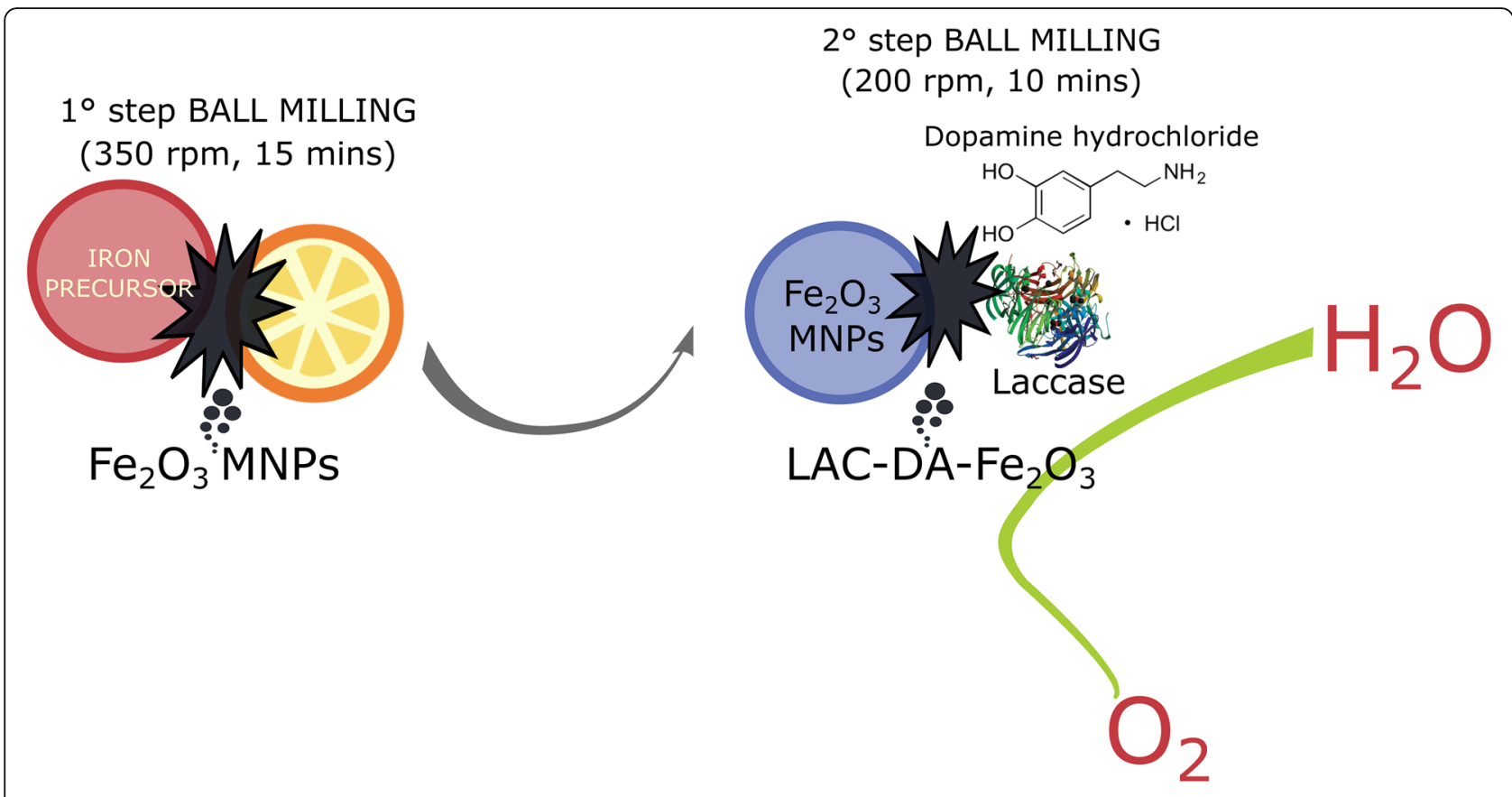

Fig. 11 Overview of the preparation and application of $L A C-D A-\mathrm{Fe}_{2} \mathrm{O}_{3}$

cobalt oxide magnetic nanoparticles $\left(\mathrm{Co}_{3} \mathrm{O}_{4}\right.$ MNPs) through a solvent-free mechanical-assisted step [45]. Firstly, dopamine (DA) hydrochloride was solubilized in water and added to pre-synthesized $\mathrm{Co}_{3} \mathrm{O}_{4}$ magnetic nanoparticles. The mixture was milled in a planetary mill (200 rpm, $10 \mathrm{~min}$ ) obtaining $\mathrm{DA}-\mathrm{Co}_{3} \mathrm{O}_{4}$. This first step was followed by another ball milling-assisted step: using the same milling parameters, a dispersion of horse hemoglobin $(\mathrm{Hb})$ in $\mathrm{NaH}_{2} \mathrm{PO}_{4}$ buffer was milled together with $\mathrm{DA}-\mathrm{Co}_{3} \mathrm{O}_{4}$, obtaining $\mathrm{Hb}-\mathrm{DA}-\mathrm{Co}_{3} \mathrm{O}_{4}$. This novel nanocomposite was used as catalyst in durable supercapacitor. The dry mechanical-assisted preparation of the biomodified catalytic material was demonstrated to be an easy, green and effective unconventional route.

Basing on the mechanical-assisted approach described above, another bioconjugate was synthetized using a redox-active protein and $\mathrm{Fe}_{2} \mathrm{O}_{3}$ nanoparticles. For the synthesis, dopamine (DA) previously coated with $\mathrm{Fe}_{2} \mathrm{O}_{3}$ particles (DA- $\mathrm{Fe}_{2} \mathrm{O}_{3}$ ) was functionalized with hemoglobin, using two successive mechanicalassisted steps [46]. The so-prepared materials were employed as catalysts to polymerize ortho-, meta- and para-substituted phenylenediamines. The products achieved through the polymerization showed outstanding fluorescence behavior and could be used in optoelectronic devices.

The mechanically functionalization of $\mathrm{Fe}_{2} \mathrm{O}_{3}$ nanoparticles with laccase has been also recently reported [47]. The procedure involved two mechanical-assisted steps and allowed the exploitation of a biomass, orange peel waste as sacrificial template and also of an enzyme for the synthesis of a bioconjugates. Firstly, $\mathrm{Fe}_{2} \mathrm{O}_{3}$ nanoparticles supported over carbon were prepared using iron nitrate and orange peel waste as carbon source using a mechanochemicalbased approach. Sequentially, a mechanical-assisted step was performed milling iron oxide magnetic nanoparticles, dopamine hydrochloride (DA-HCl)

Table 3 Summary of mechanochemically prepared bioconjugates catalysts

\begin{tabular}{|c|c|c|c|c|}
\hline Catalyst & Preparation method & Equipment & Application & Ref. \\
\hline $\mathrm{Hb}-\mathrm{DA}-\mathrm{CO}_{3} \mathrm{O}_{4}$ & $\begin{array}{l}\text { Ball milling of } \mathrm{DA}-\mathrm{HCl} \text { and } \mathrm{CO}_{3} \mathrm{O}_{4} \text { in a planetary ball for } 10 \mathrm{~min} \\
\text { at } 200 \mathrm{rpm} \text {. Ball milling of } \mathrm{Hb} \text { and } \mathrm{DA}-\mathrm{HCl}-\mathrm{CO}_{3} \mathrm{O}_{4} \text { for } 10 \mathrm{~min} \text { at } \\
200 \mathrm{rpm} \text {. Dried at } 30^{\circ} \mathrm{C} \text { for } 24 \mathrm{~h} \text {. }\end{array}$ & Retsch-PM-100 planetary ball mill & Energy storage devices & {$[45]$} \\
\hline $\mathrm{Hb}-\mathrm{DA}-\mathrm{Fe}_{2} \mathrm{O}_{3}$ & $\begin{array}{l}\text { Ball milling of } \mathrm{DA}-\mathrm{HCl} \text { and } \mathrm{Fe}_{2} \mathrm{O}_{3} \text { for } 10 \mathrm{~min} \text { at } 350 \mathrm{rpm} \text {. Ball } \\
\text { milling of } \mathrm{Hb} \text { and } \mathrm{DA}-\mathrm{HCl}-\mathrm{Fe}_{2} \mathrm{O}_{3} \text { for } 10 \mathrm{~min} \text { at } 350 \mathrm{rpm} \text {. Dried } \\
\text { at } 30^{\circ} \mathrm{C} \text { for } 24 \mathrm{~h} \text {. }\end{array}$ & Retsch-PM-100 planetary ball mill & Optoelectronic devices & [46] \\
\hline $\mathrm{LAC}-\mathrm{DA}-\mathrm{Fe}_{2} \mathrm{O}_{3}$ & $\begin{array}{l}\text { Ball milling of iron precursor and orange peel waste for } 15 \mathrm{~min} \\
\text { at } 350 \mathrm{rpm} \text {. Ball milling of laccase, } \mathrm{DA}-\mathrm{HCl} \text { and } \mathrm{Fe}_{2} \mathrm{O}_{3} \text { for } 10 \mathrm{~min} \\
\text { at } 350 \mathrm{rpm} \text {. Dried at } 100^{\circ} \mathrm{C} \text { for } 24 \mathrm{~h} \text { and heated up at } 300{ }^{\circ} \mathrm{C} \text {. }\end{array}$ & Retsch-PM-100 planetary ball mill & $\begin{array}{l}\text { Electrocatalytic reduction } \\
\text { of oxygen }\end{array}$ & {$[47]$} \\
\hline
\end{tabular}




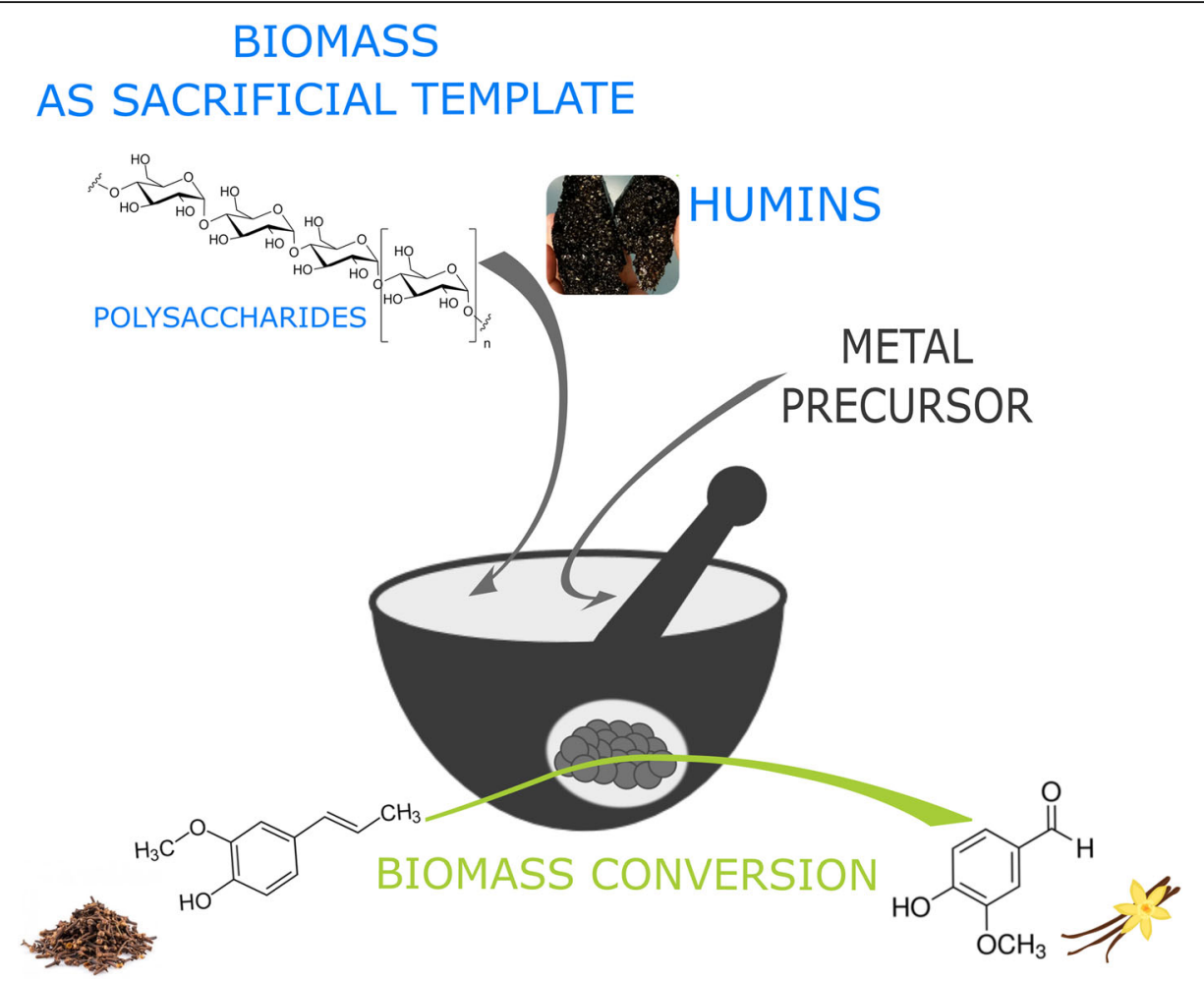

Fig. 12 Mechanochemically synthesized bio-based catalysts for biomass conversion
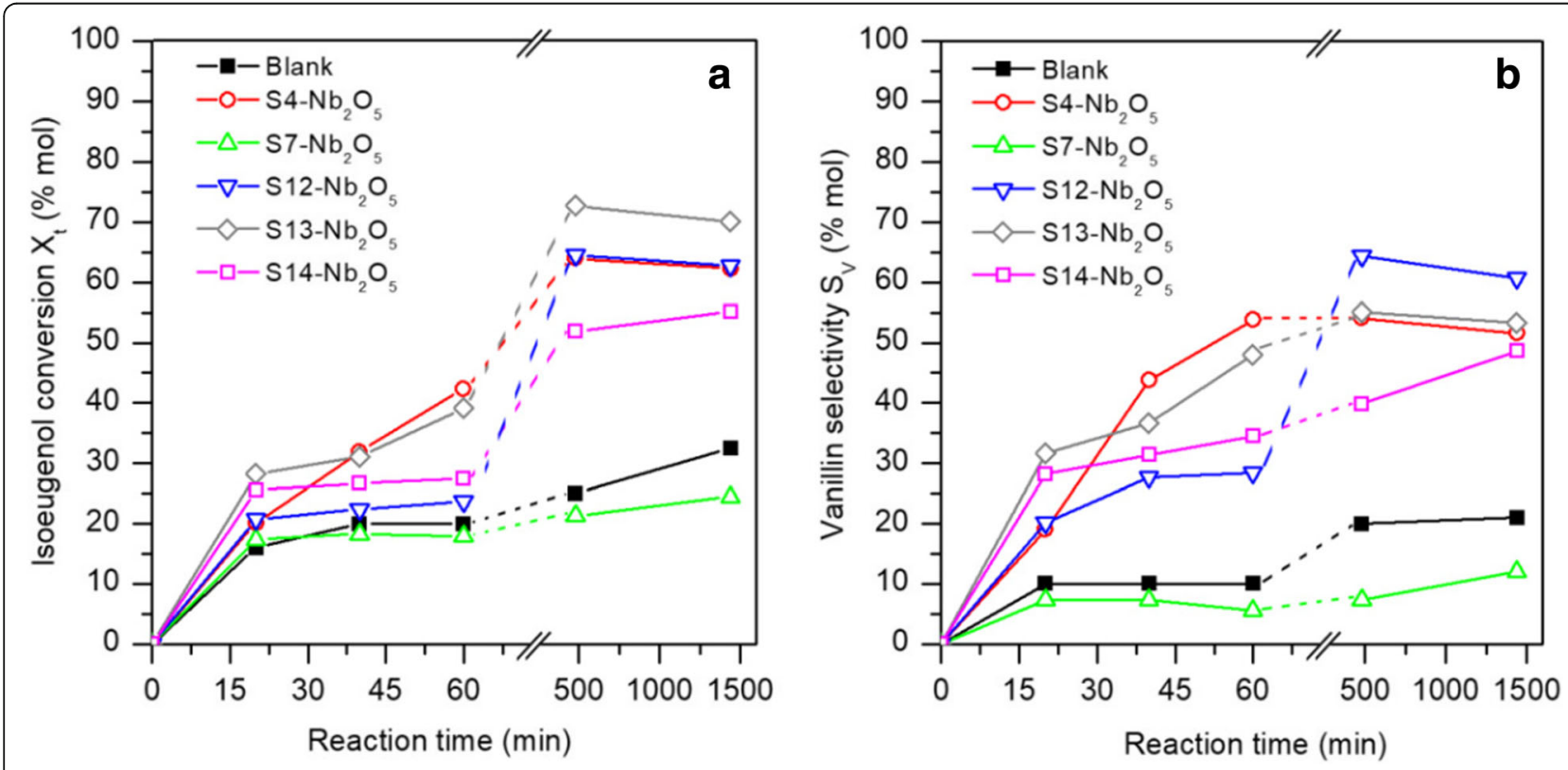

Fig. 13 a Isoeugenol conversion (\%) and $\mathbf{b}$ vanillin selectivity (\%) of mechanochemically prepared polysaccharide-based Nb catalysts. Reproduced from Ref. [49] 
Table 4 Summary of mechanochemically prepared bio-based catalysts for biomass conversion

\begin{tabular}{|c|c|c|c|c|c|}
\hline Catalyst & Biomass template & Preparation method & Equipment & Application & Ref. \\
\hline $\begin{array}{l}\text { Humin-based iron } \\
\text { oxide catalysts }\end{array}$ & Humins & $\begin{array}{l}\text { Ball milling of } \mathrm{FeNO}_{3} \cdot 9 \mathrm{H}_{2} \mathrm{O} \text { or } \mathrm{FeCl}_{2} \cdot 4 \mathrm{H}_{2} \mathrm{O} \text { with } 4 \mathrm{~g} \text { of } \\
\text { humins for } 45 \mathrm{~min} \text { at } 350 \mathrm{rpm} \text {. Materials were dried at } \\
100{ }^{\circ} \mathrm{C} \text { for } 12 \mathrm{~h} \text { and finally subjected to a calcination for } \\
4 \mathrm{~h} \text { at } 400^{\circ} \mathrm{C} \text {. }\end{array}$ & $\begin{array}{l}\text { Retsch-PM-100 } \\
\text { planetary ball mill }\end{array}$ & $\begin{array}{l}\text { Oxidation of isoeugenol } \\
\text { to vanillin }\end{array}$ & {$[48]$} \\
\hline $\begin{array}{l}\text { Polysaccharide-based } \\
\text { niobium composites }\end{array}$ & Polysaccharide & $\begin{array}{l}\text { Ball milling of ammonium niobate }(\mathrm{V}) \text { oxalate hydrate } \\
\text { and polysaccharide in a planetary ball for } 30 \text { min at } 350 \\
\text { rpm; then ovendried at } 100^{\circ} \mathrm{C} \text { for } 24 \mathrm{~h} \text { and calcination } \\
\text { at } 600^{\circ} \mathrm{C} \text { for } 3 \mathrm{~h} \text {. }\end{array}$ & $\begin{array}{l}\text { Retsch-PM-100 } \\
\text { planetary ball mill }\end{array}$ & $\begin{array}{l}\text { Oxidation of isoeugenol } \\
\text { to vanillin }\end{array}$ & [49] \\
\hline
\end{tabular}

and commercial laccase from Trametes Versicolor (LAC) for $10 \mathrm{~min}$ at $200 \mathrm{rpm}$. Finally, the materials were dried in the oven at $100{ }^{\circ} \mathrm{C}$ for $24 \mathrm{~h}$, and consecutively heated up to $300{ }^{\circ} \mathrm{C}$ for $30 \mathrm{~min}$. The bioconjugate catalysts were used in the direct electrochemically reduction of oxygen, showing good performances. Figure 11 represents an overview of the mechanical-assisted synthesis of bioconjugatebased materials and their application in the electroreduction of oxygen.

The synthetic methods and applications of the mechanochemically obtained bioconjugates materials are summarized in Table 3.

\section{Mechanochemically prepared bio-based catalysts for biomass conversion}

Other novel and captivating examples of mechanicalsynthetic protocols describe the preparation of biotemplate nanocatalysts used for the biomass conversion, as schematized in Fig. 12. This paragraph combines the two aspects previously presented: the mechanochemicalassisted synthesis of nanocatalysts for biomass conversion and the mechanical preparation of bio-based materials.

Recently, a humins valorization through a mechanicalassisted preparation of humin-based iron oxide nanocatalysts was reported [48]. Humins are a class of biowaste organic compounds derived from the catalytic conversion of biomass in acid conditions. However, they are generally an undesirable feedstock for chemical purposes. In the mechanical-assisted process $\mathrm{FeNO}_{3} \cdot 9 \mathrm{H}_{2} \mathrm{O}$ and $\mathrm{FeCl}_{2} \cdot 4 \mathrm{H}_{2} \mathrm{O}$ were used as iron precursors and these chemicals were milled with $4 \mathrm{~g}$ of humins in a planetary ball mill for 45 min at $350 \mathrm{rpm}$. Materials were subsequently dried at $100{ }^{\circ} \mathrm{C}$ for $12 \mathrm{~h}$ in the oven and finally subjected to a calcination for $4 \mathrm{~h}$ at $400{ }^{\circ} \mathrm{C}$. The so-prepared catalysts were tested in a reaction for biomass valorization. The catalysts displayed a significant activity in the production of vanillin from isoeugenol, obtaining conversion $>87 \%$. For the first time, humins were employed as sacrificial template for the mechanochemical preparation of catalysts for biomass conversion to obtain high added value products like vanillin.

In a more recent work, mechano-chemically prepared polysaccharides-based niobium nanomaterials were tested in the same isoeugenol oxidation reaction [49]. The mechanical-assisted preparation of the novel nanocatalysts was performed milling, at $350 \mathrm{rpm}$ for $30 \mathrm{~min}$, a niobium precursor and polysaccharides, derived from natural source and employed as sacrificial templates. Sequentially, the materials were ovendried at $100{ }^{\circ} \mathrm{C}$ for $24 \mathrm{~h}$ and calcined at $600{ }^{\circ} \mathrm{C}$ for $3 \mathrm{~h}$. In this study, niobium-based biotemplate composites were prepared using a green and facile mechanical-assisted process, milling a niobium precursor and different polysugars. The so-prepared materials allowed isoeugenol conversion up to $60 \%$ with selectivity to vanillin up to $60 \%$, as Fig. 13 schematically showed.

The synthetic methods and applications in the conversion of biomass of the mechanochemically obtained biobased materials are summarized in Table 4 .

\section{Conclusions and perspectives}

Selected literature examples have been used to highlight the potential and broad perspectives of the mechanicalassisted preparation of advanced catalytically active nanomaterials. Particular emphasis was given to stability and activity enhancement in view of their utilization in biomass conversion and to the mechanical-assisted synthesis of bio-based nanocatalyst. In many cases, mechanically prepared nanocatalysts exhibited comparable or improved catalytic activities respect to the activities observed in nanocatalysts synthesized by traditional methods. The described examples clearly highlighted the extraordinary characteristics of mechanochemistry. These features include greater efficiency in terms of time, costs, sustainability and reproducibility as well as the possibility to discovery new products unreproducible with traditional techniques. In addition, the solventless quality of mechanochemistry implies greener reaction conditions, low Efactor and high atom efficiency.

The chemical industry has already started the transition to sustainable technologies, including some application of mechanochemistry. Remarkably, also various patent have been successfully published [50]. One extraordinary step will be the application of biomass into mechanochemistry for the massive production of biobased materials, in order to full fill the concept of a green economy free of petroleum based chemicals. 


\section{Abbreviations}

5-MFA: 5-methylfurfuryl alcohol; $\mathrm{CO}_{3} \mathrm{O}_{4}$ MNPs: Cobalt oxide magnetic nanoparticles; DA: Dopamine; DA-HCl: Dopamine hydrochloride; g$\mathrm{C}_{3} \mathrm{~N}_{4}$ : Graphitic carbon nitride; Hb: Horse hemoglobin; LAC: Laccase

\section{Acknowledgments}

The authors gratefully acknowledge MINECO for funding under project CTQ2016-78289-P, co-financed with FEDER Funds including a contract for Camilla Cova in the framework of such project. The publication has been prepared with support from RUDN University Program 5-100.

\section{Funding}

This work was conducted in the framework of MINECO project CTQ201678289-P. The funding body (MINECO, Spain) provided support for the design of the study, analysis and interpretation of data and in writing the manuscript.

\section{Availability of data and materials}

This is a review paper and does not contain original data, which can be put in an open repository database.

\section{Authors' contributions}

$R L$ conceived of the study and participated in its design and coordination as well as revised/finalized the manuscript for submission. CC made the most substantial contributions to the draft writing of the manuscript. Both authors read and approved the final manuscript.

\section{Ethics approval and consent to participate}

Not applicable.

\section{Consent for publication}

Not applicable.

\section{Competing interests}

The authors declare that they have no competing interests.

\section{Publisher's Note}

Springer Nature remains neutral with regard to jurisdictional claims in published maps and institutional affiliations.

\section{Received: 11 March 2019 Accepted: 14 May 2019}

Published online: 11 July 2019

\section{References}

1. Fernandez-Bertran JF. Mechanochemistry: an overview. Pure Appl Chem. 1999;71(11):581-6.

2. Takacs L. Quicksilver from cinnabar: the first documented mechanochemical reaction? J Miner Met Mater Soc. 2000;52(1):12-3.

3. Takacs $\mathrm{L}$. The mechanochemical reduction of $\mathrm{AgCl}$ with metals. J Thermal Anal Calor. 2007:90:81-4

4. Takacs L. M. Carey Lea, the first mechanochemist. J Mater Sci. 2004; 39(16-17):4987-93.

5. Petruschke M. Tribochemistry. von G. HEINICKE. Acta Polym. 1985;36(7):400-1

6. James SL, Adams CJ, Bolm C, Braga D, Collier P, Friscic T, Grepioni F, Harris KDM, Hyett G, Jones W, Krebs A, Mack J, Maini L, Orpen AG, Parkin IP, Shearouse WC, Steed JW, Waddell DC. Mechanochemistry: opportunities for new and cleaner synthesis. Chem Soc Rev. 2012;41(1):413-47.

7. Xu CP, De S, Balu AM, Ojeda M, Luque R. Mechanochemical synthesis of advanced nanomaterials for catalytic applications. Chem Commun. 2015; 51(31):6698-713.

8. Balaz P, Achimovicova M, Balaz M, Billik P, Cherkezova-Zheleva Z, Criado JM, Delogu F, Dutkova E, Gaffet E, Gotor FJ, Kumar R, Mitov I, Rojac T, Senna M, Streletskii A, Wieczorek-Ciurowa K. Hallmarks of mechanochemistry: from nanoparticles to technology. Chem Soc Rev. 2013;42(18):7571-637.

9. Haas-Santo K, Fichtner M, Schubert K. Preparation of microstructure compatible porous supports by sol-gel synthesis for catalyst coatings. Appl Catal, A. 2001:220(1-2):79-92.

10. Colmenares JC, Aramendía MA, Marinas A, Marinas JM, Urbano FJ. Synthesis, characterization and photocatalytic activity of different metal-doped Titania systems. Appl Catal A. 2006;306:120-7.
11. Zuliani A, Balu AM, Luque R. Efficient and environmentally friendly microwave-assisted synthesis of catalytically active magnetic metallic $\mathrm{Ni}$ nanoparticles. ACS Sustain Chem Eng. 2017:5(12):11584-7.

12. Zuliani A, Ranjan P, Luque R, Van der Eycken V. Heterogeneously catalyzed synthesis of Imidazolones via Cycloisomerizations of propargylic Ureas using ag and au/AI SBA-15 systems. ACS Sustain Chem Eng. 2019. https://doi.org/ 10.1021/acssuschemeng.9b00198.

13. Jodlowski AD, Yepez A, Luque R, Camacho L, de Miguel G. Benign-bydesign Solventless Mechanochemical synthesis of three-, two-, and onedimensional hybrid perovskites. Angew Chem Int. 2016;55(48):14972-7.

14. Kamolphop U, Taylor SFR, Breen JP, Burch R, Delgado JJ, Chansai S, Hardacre C, Hengrasmee S, James SL. Low-temperature selective catalytic reduction $(\mathrm{SCR})$ of $\mathrm{NO}_{x}$ with $\mathrm{n}$-octane using solvent-free Mechanochemically prepared ag/ $/ \mathrm{Al}_{2} \mathrm{O}_{3}$ catalysts. ACS Catal. 2011;1:1257-62.

15. Pardeshi SK, Patil AB. Effect of morphology and crystallite size on solar photocatalytic activity of zinc oxide synthesized by solution free mechanochemical method. J Mol Catal A. 2009:308(1-2):32-40.

16. Ralphs K, Hardacre C, James SL. Application of heterogeneous catalysts prepared by mechanochemical synthesis. Chem Soc Rev. 2013:42(18):7701-18.

17. Dodd A, McKinley A, Saunders M, Tsuzuki T. Mechanochemical synthesis of nanocrystalline $\mathrm{SnO}_{2}$-ZnO photocatalysts. Nanotechnol. 2006;17(3):692-8.

18. Luque R. Benign-by-design catalysts and processes for biomass conversion. Current Op Green Sust Chem. 2016;2:6-9.

19. Corma A, Iborra S, Velty A. Chemical routes for the transformation of biomass into chemicals. Chem Rev. 2007;107:2411-502

20. Ragauskas AJ, Williams CK, Davison BH, Britovsek G, Cairney J, Eckert CA, Frederick WJ, Hallett JP, Leak DJ, Liotta CL, Mielenz JR, Murphy R, Templer R, Tschaplinski T. The path forward for biofuels and biomaterials. Science. 2006;311:484-9.

21. Franco A, De S, Balu AM, Garcia A, Luque R. Mechanochemical synthesis of graphene oxide-supported transition metal catalysts for the oxidation of isoeugenol to vanillin. Beilstein J Org Chem. 2017;13:1439-45

22. Saberi F, Rodriguez-Padron D, Doustkhah E, Ostovar S, Franco A, Shaterian HR, Luque R. Mechanochemically modified aluminosilicates for efficient oxidation of vanillyl alcohol. Catal Commun. 2019:118:65-9.

23. Cerdan K, Ouyang WY, Colmenares JC, Munoz-Batista MJ, Luque R, Balu AM. Facile mechanochemical modification of $\mathrm{g}-\mathrm{C}_{3} \mathrm{~N}_{4}$ for selective photooxidation of benzyl alcohol. Chem Eng Sci. 2019;194:78-84.

24. Yepez A, Pineda A, Garcia A, Romero AA, Luque R. Chemical transformations of glucose to value added products using cu-based catalytic systems. Phys Chem Chem Phys. 2013;15:12165-72.

25. Pineda A, Balu AM, Campelo JM, Romero AA, Carmona D, Balas F, Santamaria J, Luque R. A dry milling approach for the synthesis of highly active nanoparticles supported on porous materials. Chemsuschem. 2011;4(11):1561-5.

26. Kimling MC, Caruso RA. Sol-gel synthesis of hierarchically porous $\mathrm{TiO}_{2}$ beads using calcium alginate beads as sacrificial templates. J Mater Chem. 2012;22:4073-82.

27. Raveendran P, Fu J, Wallen SL. A simple and "green" method for the synthesis of au, ag, and au-ag alloy nanoparticles. Green Chem. 2006;8:34-8.

28. Chairam S, Poolperm C, Somsook E. Starch vermicelli template-assisted synthesis of size/shape-controlled nanoparticles. Carbohydr Polym. 2009:75:694-704.

29. Vigneshwaran N, Nachane RP, Balasubramanya RH, Varadarajan PV. A novel one-pot 'green' synthesis of stable silver nanoparticles using soluble starch. Carbohydr Res. 2006;341:2012-8.

30. Bozanic DK, Djokovic V, Blanusa J, Nair PS, Georges MK, Radhakrishnan T. Preparation and properties of nano-sized $\mathrm{ag}$ and $\mathrm{Ag}_{2} \mathrm{~S}$ particles in biopolymer matrix. Eur Phys J E. 2007:22:51-9.

31. Cai J, Liu SL, Feng J, Kimura S, Wada M, Kuga S, Zhang LN. Cellulose-silica nanocomposite aerogels by in situ formation of silica in cellulose gel. Angew Chem-Int Ed. 2012;51:2076-9.

32. El Kadib A, Molvinger $K$, Cacciaguerra T, Bousmina M, Brunel D. Chitosan templated synthesis of porous metal oxide microspheres with filamentary nanostructures. Micropor Mesopor Mater. 2011;142:301-7.

33. Sipos P, Berkesi O, Tombacz E, St Pierre TG, Webb J. Formation of spherical iron(III) oxyhydroxide nanoparticles sterically stabilized by chitosan in aqueous solutions. Inorg Biochem. 2003:95:55-63.

34. Wang BL, Tian CG, Wang L, Wang RH, Fu HG. Chitosan: a green carbon source for the synthesis of graphitic nanocarbon, tungsten carbide and graphitic nanocarbon/tungsten carbide composites. Nanotechnol. 2010:21(2):025606.

35. Laudenslager MJ, Schiffman JD, Schauer CL. Carboxymethyl chitosan as a matrix material for platinum, gold, and silver nanoparticles. Biomacromolecules. 2008;9:2682-5. 
36. Schneidermann C, Jackel N, Oswald S, Giebeler L, Presser V, Borchardt L. Solvent-free Mechanochemical synthesis of nitrogen-doped Nanoporous carbon for electrochemical energy storage. Chemsuschem. 2017:10(11):2416-24.

37. Schneidermann C, Kensy C, Otto P, Oswald S, Giebeler L, Leistenschneider D, Gratz S, Dorfler S, Kaskel S, Borchardt L. Nitrogen-doped biomass-derived carbon formed by Mechanochemical synthesis for lithium-sulfur batteries. Chemsuschem. 2019;12(1):310-9.

38. Schnepp Z, Hall SR, Hollamby MJ, Mann S. A flexible one-pot route to metal/metal oxide nanocomposites. Green Chem. 2011;13:272-5.

39. Schnepp Z, Wimbush SC, Mann S, Hall SR. Alginate-mediated routes to the selective synthesis of complex metal oxide nanostructures. Crystengcomm. 2010;12(5):1410-5.

40. Liu YD, Goebl J, Yin YD. Templated synthesis of nanostructured materials. Chem Soc Rev. 2013;42:2610-53.

41. Francavilla M, Pineda A, Romero AA, Colmenares JC, Vargas C, Monteleone M, Luque R. Efficient and simple reactive milling preparation of photocatalytically active porous $\mathrm{ZnO}$ nanostructures using biomass derived polysaccharides. Green Chem. 2014;16:2876-85.

42. Sheldon RA. Green solvents for sustainable organic synthesis: state of the art. Green Chem. 2005;7:267-78.

43. Sheldon RA. Green and sustainable manufacture of chemicals from biomass: state of the art. Green Chem. 2014;16:950-63.

44. Tsuzuki T, McCormick PG. Mechanochemical synthesis of nanoparticles. J Mater Sci. 2004;39:5143-6.

45. Rodriguez-Padron D, Puente-Santiago AR, Caballero A, Benitez A, Balu AM, Romero AA, Luque R. Mechanochemical design of hemoglobinfunctionalised magnetic nanomaterials for energy storage devices. J Mater Chem A. 2017;5:16404-11.

46. Rodriguez-Padron D, Jodlowski AD, de Miguel G, Puente-Santiago AR, Balu AM, Luque R. Synthesis of carbon-based fluorescent polymers driven by catalytically active magnetic bioconjugates. Green Chem. 2018;20:225-9.

47. Rodriguez-Padron D, Puente-Santiago AR, Caballero A, Balu AM, Romero AA, Luque R. Highly efficient direct oxygen electro-reduction by partially unfolded laccases immobilized on waste-derived magnetically separable nanoparticles. Nanoscale. 2018;10:3961-8.

48. Filiciotto L, Balu AM, Romero AA, Rodriguez-Castellon E, van der Waal JC, Luque R. Benign-by-design preparation of humin-based iron oxide catalytic nanocomposites. Green Chem. 2017:19(18):4423-34.

49. Rincon E, Garcia A, Romero AA, Serrano L, Luque R, Balu AM. Mechanochemical preparation of novel polysaccharide-supported $\mathrm{Nb}_{2} \mathrm{O}_{5}$ catalysts. Catalysts. 2019;9:38

50. Barge A, Baricco F, Cravotto G, Fretta R, Lattuada L, Ravizza C, Bracco Imaging SPA. Mechanochemical synthesis of radiographic agents intermediates. 2018. WO2018104228.

Ready to submit your research? Choose BMC and benefit from:

- fast, convenient online submission

- thorough peer review by experienced researchers in your field

- rapid publication on acceptance

- support for research data, including large and complex data types

- gold Open Access which fosters wider collaboration and increased citations

- maximum visibility for your research: over $100 \mathrm{M}$ website views per year

At $\mathrm{BMC}$, research is always in progress.

Learn more biomedcentral.com/submissions 